\title{
PEREMPUAN DALAM PERIKANAN DAN AKUAKULTUR DI KABUPATEN INDRAGIRI HILIR RIAU
}

\author{
Rujiah $^{1}$, Ali Azhar², Mulono Apriyanto², KMS Novyar Satriawan Fikri², Marlina² \\ ${ }^{1}$ Dinas Pangan Tanaman Hortikultura dan Peternakan, Kab Inhil \\ ${ }^{2}$ Universitas Islam Indragiri \\ Email: mulonoapriyanto71@gmail.com (korespondensi)
}

\begin{abstract}
In terms of participation excellence, the fisheries sector of Indragiri Hilir Regency is gender biased. Pia dominates the scene, will hold leading positions such as ownership, control, and access to the productive resources of aquaculture production systems, as well as ownership of fishing vessels and equipment in the fishing sector. These roles give them the benefit of financial by providing investment opportunities, loan facilities, and import and export licenses, among others. Despite the economic potential of small-scale fisheries and aquaculture, women invest very little in the aquaculture, artisanal and industrial sectors. Women take a secondary role in processing and marketing, delaying major decisions for male counterparts. The underlying socio-cultural norms and gender relationships emphasized by intersectionality are often barriers to owning, accessing, or controlling productive resources and other inputs. Gender mainstreaming appears to be a very recent development in the fisheries sector. The goal of the study is the reorientation of women, especially those working in small-scale fisheries, including fisheries and aquaculture, toward active and significant participation in boat owner contribution, productivity, and policy/decision-making. Secondary data and conclusions from previous studies, especially reports and reviews from other districts,compared to what is available in Indragiri Hilir Regency. As a result, we propose expanding social entrepreneurship initiatives, bootstrapping, and social capital, among other interventions, to increase women's participation in the fisheries sector.
\end{abstract}

Keywords: Fisheries, Aquaculture, Women, Gender

\begin{abstract}
Abstrak
Dalam hal keunggulan partisipasi, sektor perikanan Kabupaten Indragiri Hilir bias gender. Pia mendominasi tempat kejadian, akan memegang posisi terkemuka seperti kepemilikan, kontrol, dan akses ke sumber daya produktif sistem produksi akuakultur, serta kepemilikan kapal penangkap ikan dan peralatan di sektor perikanan. Peran-peran ini menguntungkan mereka secara finansial dengan memberikan peluang investasi, fasilitas pinjaman, dan lisensi impor dan ekspor, antara lain. Terlepas dari potensi ekonomi perikanan dan akuakultur skala kecil, perempuan berinvestasi sangat sedikit di sektor akuakultur, artisanal dan industri. Perempuan mengambil peran sekunder dalam pengolahan dan pemasaran, menunda keputusan besar untuk rekan-rekan laki-laki. Norma-norma sosial-budaya yang mendasari dan hubungan gender yang ditekankan oleh interseksionalitas sering menjadi hambatan untuk memiliki, mengakses, atau mengendalikan sumber daya produktif dan input lainnya. Pengarus utamaan gender tampaknya menjadi perkembangan yang sangat baru di sektor perikanan. Tujuan dari penelitian adalah reorientasi perempuan, terutama mereka yang bekerja di perikanan skala kecil, termasuk perikanan dan akuakultur, menuju partisipasi aktif dan signifikan dalam kontribusi pemilik kapal, produktivitas, dan kebijakan / pengambilan keputusan. Data sekunder dan kesimpulan dari penelitian sebelumnya, terutama laporan dan ulasan dari Kabupaten lain, dibandingkan dengan apa yang tersedia di Kabupaten Indragiri Hilir. Sebagai hasilnya, kami mengusulkan perluasan inisiatif kewirausahaan sosial, kapal penangkap ikan (bootstrapping), dan modal sosial, di antara intervensi lainnya, untuk meningkatkan partisipasi perempuan di sektor perikanan.
\end{abstract}

Kata kunci: Perikanan, Akuakultur, Perempuan, Gender 


\section{PENDAhUlUAN}

Perikanan skala kecil dan akuakultur adalah kontributor besar untuk ikan makanan, pendapatan dan pekerjaan untuk banyak rumah tangga dan juga memberdayakan perempuan di seluruh dunia. [1]-[3] mencatat hubungan antara dua sektor dari setiap ekonomi nasional dan keamanan gizi.

Pada keamanan gizi, ikan dan produk perikanan dikenal untuk menyediakan sumber protein hewani termurah karena mereka tersedia untuk berbagai kekuatan pembelian renda populasi berdasarkan ukuran dan kuantitas [4]-[6]. Sumber utama ikan adalah perikanan artisanal, perikanan industri, impor dan akuakultur. Di Indonesia, kedua sektor perikanan tangkap dan budaya menyumbang sekitar $2 \%$ dari Produk Domestik Bruto (PDB) nasional dan $40 \%$ dari asupan protein hewani pada tahun 2020, sementara sektor perikanan artisanal, khususnya, terkenal mempekerjakan sekitar tiga juta orang [7].

Indonesia membutuhkan 3,32 juta metrik ton ikan untuk menjaga masyarakat yang sehat. Dari permintaan ikan nasional ini, produksi dalam negeri dari semua perikanan adalah 1,123 juta metrik ton seperti pada tahun 2014. Kesenjangan antara permintaan dan penawaran telah mendorong impor besar untuk menebus defisit. Misalnya, sekitar 2 juta metrik ton diimpor pada tahun 2019 perikanan tangkap terus menurun secara global, budaya aqua tetap menjadi harapan untuk mewujudkan pasokan ikan pangan yang berkelanjutan [7].

[5], [8], [9] mencatat bahwa budidaya ikan atau akuakultur di Indragiri Hlir dimulai secara efektif lebih dari 50 tahun yang lalu. Namun, Indragiri Hilir belum menyadari potensi penuhnya dalam produksi ikan yang diperlukan untuk memenuhi permintaan domestik. Meskipun angka produksi, impor, dan kontribusi abso-lute oleh berbagai sektor perikanan mungkin berbeda berdasarkan percep-tion penulis, ada konsensus tentang kebutuhan mendesak untuk meningkatkan produksi ikan pangan dalam negeri [10], [11]. Menurut referensi, tantangan utama untuk meningkatkan produksi ikan pangan secara berkelanjutan di Indonesia tetap tidak tersedianya fasilitas kredit dan insentif lainnya, layanan penyuluhan yang buruk, dan kurangnya kebijakan dan kerangka hukum yang lebih baik [12], [13].

Keterlibatan perempuan dalam rantai nilai perikanan ditandai dengan rendahnya modal dan input teknologi.
Hal ini terlihat dari total populasi tergantung pada perikanan tangkap, 47 persen adalah perempuan [14], [15]. Tenaga kerja perempuan, khususnya di sektor perikanan skala kecil cenderung tinggi. Dalam akuakultur, salah satu sektor produksi primer yang paling cepat berkembang, kontribusi perempuan meningkat secara proporsional.

Perempuan berkontribusi secara signifikan terhadap ekonomi nasional melalui partisipasi mereka dalam produksi pertanian, pengolahan dan pemasaran, namun lebih dari 60 persen orang miskin di dunia adalah perempuan dan mereka memiliki lebih sedikit pilihan daripada lakilaki untuk melarikan diri dari kemiskinan [7], [16].

\section{TINJAUAN PUSTAKA}

\subsection{Potensi Perikanan Indonesia}

Indonesia merupakan negara kepulauan yang memiliki luas perairan laut terbesar diantara negara-negara Asia serta memiliki garis pantai terpanjang di dunia. Potensi perikanan yang demikian besar belum dimanfaatkan secara optimal, sehingga perlu berbagai kebijakan untuk mendorong tercapainya pemanfaatan yang optimal tersebut.Pembangunan perikanan dilakukan melalui upaya peningkatan produktivitas dan efisiensi usaha, yang pada gilirannya diharapkan dapat meningkatkan produksi perikanan yang diarahkan untuk meningkatkan konsumsi, penerimaan devisa dan penyediaan bahan baku industri dalam negeri [17].

Keputusan Menteri Kelautan dan Perikanan Nomor 47/KEPMEN-KP/2016 tentang estimasi potensi, jumlah hasil tangkapan yng diperbolehkan (JTB) dan tingkat pemanfaatan, merupakan salah satu upaya untuk mengoptimalkan pemanfaatan sumber daya ikan di Wilayah Pengelolaan Perikanan Negara Republik Indonesia (WPP NRI). Kebijakan tersebut merupakan KEPMEN terbaru berdasarkan hasil kajian stok pada tahun 2015. Kebijakan awal tentang potensi ikan laut dan Jumlah Tangkapan yang Diperbolehkan (JTB) beberapa kelompok species ikan seperti, pelagis besar, pelagis kecil, demersal, udang, cumicumi, ikan hias, moluska dan teripang, benih alam komersial, ikan konsumsi perairan karang pertama kali ditetapkan melalui Keputusan Menteri Pertanian No. 995/Kpts/IK 210/9/99 [18], [19].

Pada tahun 2008 dilakukan kembali kajian ulang secara kuantitatif terhadap empat kelompok spesies pada masing masing WPP, dimana metoda yang dipergunakan adalah Model Surplus Produksi yang hanya didasari oleh dua variabel input yaitu hasil tangkapan (Catch) 
dan upaya penagkapan (Effort). Sepanjang sejarah kajian stok yang dilakukan, kajian ulang tahun 2015 merupakan kajian yang akurasinya lebih baik, karena hampir $80 \%$ data yang digunakan adalah data primer yang diperoleh dengan metode akustik [14], [20], [21].

Kapal pukat cincin yang berbasis di Tanjungbalai dan Belawan sebagian besar beroperasi di perairan Selat Malaka bagian utara terutama di wilayah perairan Lhokseumawe sampai Langsa. Sementara daerah penangkapan kapal pukat cincin yang berbasis di Lampulo (Banda Aceh) terutama di wilayah perairan antara Pidie dan sebelah barat daya Pulau Beras (Pulau Weh). Hasil tangkapan untuk jenis ikan pelagis kecil didominasi oleh tiga spesies ikan layang yaitu layang biasa (Decapterus russelli), layang deles (Decapterus macrosoma) dan layang biru (Decapterus macarellus). Ketiga jenis ikan layang tersebut memberi kontribusi sekitar $61 \%$ dari hasil tangkapan total. Jenis ikan pelagis kecil lain yang didaratkan adalah ikan banyar (Rastrelliger kanagurta) 10\%, ikan selar bentong (Selar crumenophthalmus) $7 \%$ dan ikan tembang (Sardinella gibbosa) 4\%.

\subsection{Sebaran Penangkapan}

Penyebaran sumber daya ikan demersal seperti ikan petek, kuniran, bawal hitam, bawal putih, layur, tigawaja, beloso, kurisi, kurau dan swanggi mencapai wilayah perairan hingga 4 mil dari pantai, pada kedalaman antara 20-50 m, seperti di perairan sekitar Pulau Berhala, Pulau Pandan, Panipahan dan perairan Aceh Timur. Ikan demersal yang habitatnya terdapat di perairan relatif dalam; jenis gerot-gerot, kakap merah, kerapu dan lencam terutama terdapat di perairan Selat Malaka bagian utara yang langsung berbatasan dengan Laut Andaman. Daerah penangkapan ikan kapal pukat ikan (PI) yang berbasis di Belawan umumnya di perairan Padang Cermin, Tanjungbalai Asahan, Panipahan, sekitar Pulau Berhala dan Pulau Jemur [22]. Daerah penangkapan ikan dengan pukat apung (longbag set net/LBSN) yang berbasis di Tanjungbalai Asahan adalah di perairan Pulau Berhala, P. Salamon, Panipahan, P.Jemur, Tanjung Api dan Tanjung Bagan. Wilayah perairan ini mempunyai kedalaman antara 30-50m. Daerah penangkapan ikan demersal dengan alat tangkap lampara dasar dan trammel net dengan ukuran kapal antara 10-20GT umumnya terdapat di pantai timur Langsa, Lhokseumawe dan Pidie.

Famili ikan demersal yang paling dominan diperoleh yaitu famili Scianidae (gulamah) dan Ephippidae yang masingmasing sebesar $23,20 \%$ dan $15,16 \%$ dari total hasil tangkapan ikan demersal [23]. Sementara itu spesies ikan demersal yang mendominasi adalah jenis Johnius amblycephalus, Drepane punctata, dan Pennahia macrocephalus, yang masingmasing sebanyak 11,89\%, 9,67\% dan 8,37\%. Spesies Johnius amblycephalus dan Pennahia macrocephalus merupakan anggota dari famili Scianidae sedangkan Drepane punctata merupakan anggota dari famili Ephippidae. Jenis ikan demersal lain yang tertangkap memiliki kontribusi terhadap produksi kurang dari $6 \%$ seperti jenis ikan beloso (Saurida micropectoralis dan Saurida undosquamis) dan kuniran/biji nangka (Upeneus Iuzonius dan Upeneus sulphureus).

\section{METODOLOGI PENELITIAN}

Dalam penelitian ini, kami menggunakan survei, pengamatan lapangan, wawancara terstruktur menggunakan kuesioner dalam pengaturan dis-cussion-kelompok fokus dan informan kunci hubungan masyarakat [24].

Kami berusaha untuk mengetahui peran apa yang dimainkan perempuan dalam usaha akuakultur dan perikanan skala kecil di daerah tersebut. Pertanyaan tentang kepemilikan, akses ke sumber daya, pengambilan keputusan/kebijakan, dan kekhawatiran mereka dibahas.

Wawancara dan diskusi diadakan di pondok-pondok, dermaga dan pelabuhan pendaratan di pemukiman nelayan. Kami juga meninjau literatur yang tersedia dan mengekstraksi data sekunder untuk evaluasi [25].

\section{HASIL DAN PEMBAHASAN}

Hasil kami menunjukkan tren serupa di sektor akuakultur dan perikanan skala kecil. Di sektor akuakultur, perempuan tidak memiliki pertanian, kecuali untuk usaha keluarga bersama. Bahkan pada saat itu, partisipasi mereka terbatas. Di sektor perikanan skala kecil, perempuan memainkan peran yang lebih besar [14], [21].

Pada hasil perikanan jenis gastropoda dan moluska seperti kerang secara umum untuk perempuan, dieksploitasi sebagai pengumpul. Selain mengumpulkan moluska yang dapat dimakan, perempuan juga bertanggung jawab atas pengolahannya. Perempuan tidak memiliki perahu nelayan, jaring ikan dan peralatan memancing lainnya. Namun, perempuan bisa menjadi pemodal atau mensubsidi akuisisi fasilitas ini dengan imbalan harga yang dikurangi untuk tangkapan mendarat atau produk yang dipanen [14], [21]. .

Salah satu kendala adalah akses ke kredit, meskipun sudah ada kebijakan nasional tentang kredit kepada petani dan nelayan belum ramah 
kepada pembudidaya ikan pada umumnya, terlebih perempuan. Namun, kebijakan kredit menjadi lebih sensitif gender, akses perempuan dan laki-laki adalah sama.

Bank Indonesia (BI) telah memperkenalkan program Kresit Usaha Kecil (KUR) untuk petani dan nelayan melalui Bank BUMN ataupun swasta yang ada di Kabupaten Indragiri Hilir. Skema ini dirancang tidak hanya untuk meningkatkan produksi pertanian di Indonesia, tetapi juga untuk menciptakan hubungan antara produksi dan konsumsi [26], [27].

Program kebijakan berada pada tahap awal, sangat penting bagi perempuan untuk mengambil keuntungan dan membangun struktur yang berkelanjutan. Perempuan harus mengambil inisiatif; menginvestasikan dan mengembangkan bisnis perikanan; mengambil responsibilitas dan mendefinisikan peran untuk diri mereka sendiri; Seharusnya tidak bergantung pada pria atau menunggu peran yang ditugaskan. Hal ini juga pada tahap lepas landas ini bahwa perempuan-pengusaha pemula didorong untuk mengatur ke dalam jaringan sosial dan masyarakat koperasi untuk saling menguntungkan.

Perempuan juga didorong untuk memaksimalkan potensi kewirausahaan mereka di subsektor perikanan ekonomi melalui modal sosial. Menurut [26], [27] mencatat bahwa modal sosial adalah strategi mata pencaharian yang sukses untuk mengatasi kurangnya bantuan keuangan dan informasi pasar, menambahkan bahwa kompetensi dalam perdagangan secara positif lebih dipengaruhi oleh kemampuan untuk membangun jaringan kepercayaan.

Meskipun begitu banyak manfaat dan potensi, beberapa perempuan tidak termasuk dalam koperasi karena ketidaktahuan sehingga kegiatan ekonomi mereka atau kurangnya akses ke pengetahuan tentang pembentukan dan keterlibatan dalam koperasi perikanan atau asosiasi informal [26], [27].

Juga jelas bahwa dengan keanggotaan koperasi perikanan, perempuan masih cenderung memiliki aksesibilitas yang lebih rendah terhadap sumber daya produktif daripada rekan-rekan pria mereka. Misalnya, perbandingan perempuan dalam koperasi, asosiasi, atau kelompok gender perempuan yang hanya dan campuran menunjukkan bahwa lebih sedikit perempuan yang memanfaatkan peluang keanggotaan koperasi untuk mendanai bisnis perikanan mereka [26].

Perumusan kebijakan yang lebih baik untuk meningkatkan pengarus utamaan gender dalam berbagai intervensi pemerintah [26], [27].
Sekilas menunjukkan bahwa rencana tindakan khusus pemerintah untuk mengatasi kesenjangan gender di Sektor Perikanan disesuaikan dengan pemberdayaan perempuan dalam akuakultur, salah satu rantai nilai prioritas yang dipilih yang ditargetkan untuk pembangunan.

\section{KESIMPULAN DAN SARAN}

Perlakuan terhadap perempuan nelayan belum dianggap setara peranya dengan nelayan laki-laki. Meskipun peran perempuan dalam perikanan dan kemajuan perikanan di Kabupaten Indragiri Hilir cukup tinggi. Dalam proses produksi maupun proses pengolahan bahkan proses pemasaran. Dalam akses kepada pendanaan bank perempuan nelayan juga masih kurang diperhatikan seperti mendapatkan akses perbankan yang masih susah.

\section{DAFTAR PUSTAKA}

[1] M. Ramli and M. Apriyanto, "MANAJEMEN KEUANGAN UNTUK MENINGKATKAN PEREKONOMIAN KELUARGA DI MASA PANDEMI COVID19," Selodang Mayang, vol. 6, no. 3, pp. 145-152, 2020.

[2] M. Apriyanto, N. Nursida, H. Mardesci, and $\ldots$, "PELATIHAN TEKNIS PENANAMAN PADI BAGI PENYULUH PERTANIAN," J-Abdi J. ..., 2021, [Online]. Available: http://repository.unisi.ac.id/148/.

[3] Y. Riono and M. Apriyanto, "Pemanfaatan Abu Sekam Padi dalam Inovasi Pemupukan Kacang Hijau (Vigna Radiate L) Di Lahan Gambut," Selodang Mayang J. IIm. ..., 2020, [Online]. Available: https://ojs.selodangmayang.com/index. php/bappeda/article/view/164.

[4] N. F. RAHMAWATI, PEMBUATAN BIOETANOL DARI RUMPUT LAUT Eucheuma cottonii DENGAN VARIASI KONSENTRASI ASAM KLORIDA PADA PROSES HIDROLISIS. eprints.unram.ac.id, 2018.

[5] ..., F. Fathuddin, and N. F. Nursida, "Pemanfaatan Ruang Akuakultur Potensial melalui Diseminasi Teknologi Budidaya Metode Vertikal untuk Meningkatkan Kapasitas Pembudidaya dan Produksi ...," Engagem. J. ..., 2021, [Online]. Available: http://engagement.fkdp.or.id/index.php /engagement/article/view/644.

[6] O. Rohmawati, ... ) Pada Budidaya Ikan Nila (Oreochromis niloticus) Sistem 
Akuaponik Dengan Tanaman Kangkung (Ipomoea aquatica), Pakcoy (Brassica rapa L.) dan Bayam merah .... repository.unair.ac.id, 2020.

[7] Hartono, Kabupaten Indragiri Hilir Dalam Angka 2020. 2020.

[8] M. Apriyanto, K. M. S. N. S. Fikri, and A. Azhar, "Pendampingan Santri untuk Penurunan Tingkat Pelanggaran Lalu Lintas," Magistrorum Sch. J. Pengabdi. Masy., vol. 1, no. 2, pp. 238-247, 2020.

[9] A. Azhar and K. Novyar Satriawan Fikri, "Study of law number 9 off regarding freedom of speech in publice," Int. $J$. Sci. Technol. Res., vol. 9, no. 1, pp. 4002-4006, 2020.

[10] E. Barades, A. Alimuddin, and A. O. Sudrajat, "Elektroporasi dan transplantasi sel testikular dengan label GFP pada ikan nila Electroporation and GFP-labelled transplantation of testicular cells in Nile tilapia," $J$. Akuakultur Indones., vol. 12, no. 2, pp. 186-192, 2013, doi: 10.19027/jai.12.186-192.

[11] F. Masud, D. W. Laily, and $M$. Makhfudhoh, "Analisis Usaha Terasi Udang Rebon (Acetes indicus) Di Kabupaten Lamongan," Grouper, vol. 11 , no. 2, p. 1, 2020, doi: 10.30736/grouper.v11i2.69.

[12] L. K. Latiro and S. A. Lawelle, "STRATEGI PENGEMBANGAN USAHA OLAHAN IKAN CAKALANG ASAP (STUDI KASUS CV. OME TRD COY DI PPS KENDARI KELURAHAN PUDAY KECAMATAN ...," J. Sos. Ekon. Perikan., [Online]. Available: http://ojs.uho.ac.id/index.php/JSEP/arti cle/view/8968.

[13] W. P. Lokapirnasari, O. S. Widodo, and ..., "Potensi Bakteri Lactococcus sp. dan Lactobacillus sp. untuk Peningkatan Kualitas Limbah Kulit Kacang Sebagai Alternatif Bahan Pakan [Potential of Lactococcus sp ...," J. I/m. Perikan. ..., 2018, [Online]. Available: https://www.e-

journal.unair.ac.id/JIPK/article/view/854 7.

[14] E. Harahap, "Rasio Jenis Kelamin Udang Galah (Macrobrachium rosenbergii) Pada Kondisi Perairan Sungai Barumun Kabupaten Labuhanbatu Selatan," Konserv. Hayati, 2020, [Online]. Available: https://ejournal.unib.ac.id/index.php/ha yati/article/view/12472.

[15] N. Masriqah, S. A. Aslamyah, and Z. Zainuddin, "Retensi Nutrien Pakan pada
Berbagai Dosis Ubi Jalar (Ipomea batatas) dalam Pakan Sebagai Prebiotik bagi Lactobacillus sp. pada Udang Vaname ...," Proceeding Simposium Nasional Kelautan .... 2019, [Online]. Available:

https://journal.unhas.ac.id/index.php/p roceedingsimnaskp/article/view/7753/4 156.

[16] S. Ulya and D. S. Ria, "Pemanfaatan Limbah Kepala Udang Windu ( Penaeus monodon ) Untuk Pembuatan Terasi Dengan Kajian Penambahan Garam Dan Lama Fermentasi ( The use of Penaeus monodon shrimp head waste for Terasi product The study of salt addition and fermentation time)," J. Rekapangan, vol. 10, no. 1, pp. 67-72, 2016, [Online]. Available: http://ejournal.upnjatim.ac.id/index.ph p/teknologipangan/article/download/700/579.

[17] A. Azhar, K. N. S. Fikri, V. A. Siregar, and M. Apriyanto, "PENCEGAHAN, PEMBERANTASAN, PENYALAHGUNAAN DAN PEREDARAN GELAP NARKOBA (P4GN) pada PESANTREN," J. Inov. Penelit., vol. 1, no. 3, pp. 2463-2468, 2020.

[18] M. Apriyanto, K. N. S. Fikri, and A. Azhar, "Sosialisasi Konsep Lahan Pertanian Pangan Berkelanjutan Di Kecamatan Batang Tuaka, Kabupaten Indragiri Hilir," PaKMas (Jurnal Pengabdi. Kpd. Masyarakat), vol. 1, no. 1, pp. 8-14, 2021.

[19] N. Nurhayati and M. Apriyanto, "Sensory evaluation of chocolate bar production materials of dry cocoa seeds in various fermentation treatments," Czech J. Food Sci., vol. 39, no. 1, pp. 58-62, 2021, doi: 10.17221/272/2020CJFS.

[20] S. R. Harahap, D. Sushanty, Y. Riono, and R. Z. Surya, "PENERAPAN TEKNIK STIMULUS MUTILASI DALAM BUDIDAYA KEPITING SOKA (SOFT-SHELLED CRABS) DI DESA PULAU CAWAN KABUPATEN ...," MINDA BAHARU. journal.unrika.ac.id, 2019, [Online]. Available: https://journal.unrika.ac.id/index.php/M NDBHRU/article/viewFile/2024/1513.

[21] H. F. Ahlina, Y. Riono, and S. R. Harahap, "Pengaruh penggunaan jenis wadah yang berbeda terhadap pertumbuhan dan kelangsungan hidup ikan betutu (Oxyeleotris marmorata Blkr.)," Acta Aquat. Aquat. Sci. ..., 2019, [Online]. Available: https://ojs.unimal.ac.id/acta- 
aquatica/article/view/1666.

[22] I. Y. Harahap and M. E. S. Lubis, "Penggunaan Model Jaringan Saraf Tiruan (Artificial Neuron Network) Untuk Memprediksi Hasil Tandan Buah Segar (TBS) Kelapa Sawit Berdasar Curah Hujan ...," Jurnal Penelitian Kelapa Sawit. core.ac.uk, 2018, [Online]. Available:

https://core.ac.uk/download/pdf/23126 4740.pdf.

[23] S. Bandyopadhyay and S. K. De, "Materials and methods," in Advances in Asian Human-Environmental Research, no. 9783319410173, 2015, pp. 47-59.

[24] M. Apriyanto, "Keaslian Penelitian dan Hipotesis/Pertanyaan Penelitian," in Metodollogi Penelitian Pertanian, Yogyakarta: Nuta Media, Yogyakarta, 2021.

[25] M. Apriyanto and K. N. S. Fikri, "Naskah Akademik LP2B Kabupaten Indragiri Hilir," 2021.

[26] O. R. Risma, T. Zulham, and ..., "Pengaruh Suku Bunga, Produk Domestik Bruto Dan Nilai Tukar Terhadap Ekspor Di Indonesia," JPED (Jurnal Perspekt. ..., 2018, [Online]. Available:

http://www.jurnal.unsyiah.ac.id/JPED/a rticle/view/13027.

[27]A. U. Maghfiroh and R. R. Dewi, "FAKTOR-FAKTOR YANG MEMPENGARUHI PROFITABIITAS PERBANKAN STUDI EMPIRIS PADA PERBANKAN YANG TERDAFTAR DI BEI PERIODE 2014-2017," PROSEDING Semin. ..., 2020, [Online]. Available: http://openjournal.unpam.ac.id/index.p hp/SNU/article/view/2506. 